\title{
Erratum
}

\section{Robust high-throughput kinetic analysis of apoptosis with real-time high-content live-cell imaging}

\author{
Jesse D Gelles and Jerry Edward Chipuk
}

Cell Death and Disease (2017) 8, e2758; doi:10.1038/cddis.2017.156; published online 4 May 2017

Correction to: Cell Death and Disease (2016) 7, e2493; doi:10.1038/cddis.2016.332; published online 1 December 2016.

Since publication it has been noticed that an error during typesetting has led to the second author Jerry E Chipuk being incorrectly listed in PubMed as Edward Chipuk J. The publisher would like to apologise for any inconvenience caused. (c) (i) Cell Death and Disease is an open-access journal published by Nature Publishing Group. This work is licensed under a Creative Commons Attribution 4.0 International License. The images or other third party material in this article are included in the article's Creative Commons license, unless indicated otherwise in the credit line; if the material is not included under the Creative Commons license, users will need to obtain permission from the license holder to reproduce the material. To view a copy of this license, visit http://creativecommons.org/licenses/by/4.0/

(C) The Author(s) 2017 